\section{HAK PENDIDIKAN ANAK PENYANDANG DISABILITAS DALAM PRESFEKTIF HAK ASASI MANUSIA ${ }^{1}$ \\ Oleh: Natalia Zhaciko Mozes ${ }^{2}$ \\ Dani R. Pinasang ${ }^{3}$ \\ Donna O. Setiabudhi ${ }^{4}$}

\section{ABSTRAK}

Pendekatan yang digunakan dalam penelitian ini antara lain status approach (pendekatan perundang-undangan) dan analytical or conceptual approach (pendekatan analitik atau konseptual). Data sekunder berupa penelitian kepustakaan yang dilakukan terhadap berbagai macam sumber-sumber bahan hukum. Untuk memperoleh hasil yang akurat dan signifikan, data yang dikumpulkan melalui studi pustaka yang dihimpun dan diolah dengan melakukan pendekatan yuridis normatif. Hasil penelitian ini menunjukan bahwa pelaksanaan mengenai pengaturan hak pendidikan anak penyandang disabilitas sebagai bentuk RAN-HAM terjadi kesenjangan antara program yang dibuat dan pelaksanaannya dan sampai saatnya belum terpenuhinya hak pendidikan anak disabilitas. $\mathrm{Di}$ Indonesia terdapat berbagai kasus isu anak disabilitas yang ditolak oleh sekolah dengan berbagai alasan. Akomodasi yang layak pun belum terjamin dalam pendidikan inklusi sehingga dalam menjamin hak pendidikan anak pendidikan melalui teori negara kesejahteraan agar negara, pemerintah bahkan masyarakan memperlakukan anak penyandang disabilitas secara adil dan nondiskriminasi. Namun, dalam fenomena isu anak disabilitas terjadi pelanggaran hak asasi manusia bentuk diskriminasi dalam menolak anak disabilitas untuk memperoleh pendidikan inklusif.

Kata Kunci: Hak Pendidikan, Anak, Disabilitas, Hak Asasi Manusia

\section{PENDAHULUAN}

\section{A. Latar Belakang Masalah}

Tindak Penegakan hak asasi manusia di Indonesia salah satu amanat reformasi. Upaya perubahan yang telah dilakukan dalam bidang hukum dengan memasukan jaminan hak asasi

\footnotetext{
${ }^{1}$ Artikel Tesis.

${ }^{2}$ Mahasiswa pada Pascasarjana Unsrat, NIM. 18202108058

${ }^{3}$ Fakultas Hukum Unsrat, Doktor IImu Hukum

${ }^{4}$ Fakultas Hukum Unsrat, Doktor IImu Hukum
}

manusia bagi warga negara dalam konstitusi, yaitu Undang-undang Dasar Negara Republik Indonesia 1945. Tanggung jawab negara khususnya pemerintah didasarkan pada alenia keempat Pembukaan Undang-Undang Dasar 1945 (UUD 1945) yang menyebutkan bahwa tujuan pembentukan negara Indonesia, diantaranya melindungi segenap bangsa Indonesia, memajukan kesejahteraan bangsa, dan mencerdaskan kehidupan bangsa.

Penyandang disabilitas, pada kenyataannya merupakan orang-orang yang rentan terhadap bentuk-bentuk diskriminasi atau orang-orang yang termarginalkan terlebih anak-anak dan wanita yang rentan terhadap perlakuan diskriminasi ganda. Salah satu bentuk nyata adalah masih meluasnya pandangan miring kepada kelompok penyandang disabilitas efek domino nya tidak kecil ${ }^{5}$. Dalam UndangUndang Dasar Negara Republik Indonesia Tahun 1945 jaminan mengenai hak dan perlindungan diskriminatif sudah tertuang dan diamanatkan di dalamnya, pada Pasal $28 \mathrm{H}$ (ayat) 2 yang menyebutkan bahwa :

"Setiap orang berhak mendapat kemudahan dan perlakuan khusus untuk memperoleh kesempatan dan manfaat yang sama guna mencapai persamaan dan keadilan".

Undang-undang Dasar 1945 menjamin dan menghormati harkat, martabat manusia yang secara kodrati melekat pada diri manusia bersifat universal, kekal, langgeng, dihormati, dipertahankan dan dijunjung tinggi oleh Negara Republik Indonesia. Perlindungan dan jaminan hak asasi tidak hanya diberikan kepada warga Negara yang memiliki kesempurnaan secara fisik dan mental, sehingga perlindungan hak kepada kelompok rentan seperti anak penyandang disabilitas perlu ditingkatkan.

Negara Indonesia wajib untuk melindungi dan mensejahterakan seluruh warga negaranya tanpa membeda-bedakan baik dari agama, ras, bahasa, suku, budaya, agama, warna kulit ataupun kondisi fisik mereka sekalipun. Seperti halnya dengan warga negara Indonesia yang mengalami keterbatasan interaksi yang diakibatkan oleh

\footnotetext{
${ }^{5}$ Majda El Muhtaj. 2009. Dimensi-dimensi HAM Mengurai Hak Ekonomi, Sosial, dan Budaya. Jakarta: PT. Raja Grafindo Persada. hlm.278.
} 
kelainan fisik, mental, intelektual, sensorik dan/atau motorik, yang kemudian disebut sebagai penyandang disabilitas. Sebagai bagian warga negara Indonesia, maka penyandang disabilitas secara konstitusional mempunyai hak dan kedudukan yang sama di depan hukum dan pemerintahan.

Pasal 1 Undang-Undang Nomor 39 Tahun 1999 tentang Hak Asasi Manusia menjelaskan bahwa Hak Asasi Manusia adalah seperangkat hak yang melekat pada hakikat dan keberadaan manusia sebagai makhluk Tuhan Yang Maha Esa dan merupakan anugerahnya yang wajib dihormati, dijunjung tinggi dan dilindungi oleh negara, hukum dan pemerintah, dan setiap orang demi kehormatan serta perlindungan harkat dan martabat manusia.

Pemerintah wajib dan bertanggung jawab menghormati, melindungi, menegakkan, dan memajukan hak asasi manusia yang diatur dalam Undang-Undang No. 39 tahun 1999 tentang Hak Asasi Manusia, peraturan perundangan lain dan hukum internasioanal tentang hak asasi manusia yang diterima oleh negara Republik Indonesia. Selain itu manusia memiliki HAM bukan karena diberikan kepadanya oleh masyarakat hukum positif, namun semata-mata berdasarkan martabatnya sebagai manusia. HAM secara internasional telah diakui sebagai nilai-nilai, standar atau aturan perundang-undangan yang disepakati bersama yang mengatur negara dalam berinteraksi dengan masyarakatnya. Jadi HAM mengatur negara terkait denngan hal-hal yang tidak boleh dilakukan terhadap warganya, tetapi sekaligus mengarahkan apa yang harus dilakukan oleh negara.

Perlindungan dan jaminan hak tidak hanya diberikan kepada warga negara yang memiliki kesempurnaan secara fisik dan mental. Perlindungan hak bagi kelompok rentan seperti penyandang disabilitas perlu ditingkatkan. Penyandang disabilitas harus mendapat perlindungan. Pasal 1 ayat (5) UU No. 8 tahun 2016 menentukan perlindungan terhadap penyandang disabilitas merupakan upaya yang dilakukan secara sadar untuk melindungi, mengayomi dan memperkuat hak penyandang disabilitas. ${ }^{6}$

Negara seharusnya terlibat langsung dalam usaha-usaha kesejahteraan rakyat, seperti secara langsung menyediakan berbagai bentuk pelayanan dasar, seperti pelayanan pendidikan, kesehatan maupun pelayananpelayanan publik lainnya. Namun kembali pada realita, bahwa ada begitu banyak hambatan, pembatasan, kesulitan, pengurangan bahkan penghilangan hak bagi penyandang disabilitas dalam memenuhi hakhaknya.

Undang-Undang 35 tahun 2014 tentang Perubahan atas Undang-Undang Nomor 23 tahun 2002 tentang Perlindungan Anak diatur diberbagai pasal yang diatarnya mewajibkan dan memberikan tanggung jawab untuk menghormati pemeuhan hak anak tanpa membedakan suku, agama, ras, golongan, jenis kelamin, etnik, budaya dan bahasa, status hukum, untuk kelahiran, dan kondisi fisik dan/atau mental, serta melindungi dan menghormati hak anak. Kemudian dari undang-undang ini pemerintah daerah berkewajiban dan bertanggung jawab merumuskan dan melaksanakan dan mendukung kebijakan nasional dalam penyelenggaraan perlindungan anak di daerah yang dapat mewujudkan melalui upaya daerah membangun kabupaten/kota layak anak serta memberikan dukungan saran, prasarana dan ketersedian sumber daya manusia dalam penyelenggaraan perlindungan.

Landasan utama pendidikan di Indonesia sendiri sudah tertuang dalam Undang-Undang Nomor 20 Tahun 2003 tentang Sistem Pendidikan Nasional. Dalam Pasal 5 (ayat) 1 di jelaskan bahwa setiap warga negara mempunyai hak yang sama untuk memperoleh pendidikan yang bermutu. Namun dalam UndangUndang ini tidak memberikan jaminan yang tegas untuk pendidikan bagi penyandang disabilitas. Sistem Pendidikan Nasional harus mampu

\footnotetext{
${ }^{6}$ Majda El Muhtaj. 2008. Dimensi-Dimensi HAM Mengurai Hak Ekonomi, Sosial dan Budaya. Raja Grafindo Persada: Jakarta. hlm. 273. Bandingkan Budiyono, Muhtadi, Ade Arief Firmansyah. 2015. Dekonstruksi Urusan Pemerintahan Konkuren dalam Undang-Undang Pemerintahan Daerah. Kanun Jurnal IImu Hukum No. 67 Th XVII. hIm. 419-432.
} 
menjamin pemerataan kesempatan pendidikan bagi semua, termasuk penyandang disabilitas

Pendidikan bukan sebuah investasi yang bernilai ekonomi akan tetapi sebagai suatu investasi untuk mendapatkan derajat yang lebih tinggi dalam kehidupan dunia ini. Oleh karena itu pendidikan dapat memeberikan banyak manfaat baik kepada diri sendiri dan orang lain.

Pemerintah terus berupaya meningkatkan penghormatan, perlindungan, pemenuhan, penegakan, dan pemajuan HAM bagi seluruh lapisan masyarakat terlebih khusus penyandang disabilitasmelalui Peraturan Presiden RI Nomor 75 tahun 2015 tentang Rencana Aksi Nasional Hak Asasi Manusia Tahun 2015-2019. Dalam pelaksanaan pemenuhan hak penyandang disabilitas masih belum optimal dan memiliki kendalakendala untuk mewujudkan hak pendidikan bagi anak penyandang disabilitas dan salah satu kendala yaitu dalam akomodasi di sekolah.

\section{B. Rumusan Masalah}

Berdasarkan latar belakang permasalahan yang telah dikemukakan di atas, maka dapat dirumuskan beberapa masalah sebagai berikut :

1. Bagaimanakah pengaturan instrumen hukum nasional dan instrumen hukum internasional mengenai hak pendidikan anak disabilitas?

2. Bagaimanakah pelaksanaanmengenai pengaturan hak pendidikan anak penyandang disabilitas prespektif Hak Asasi Manusia?

\section{Tujuan Penelitian}

Berdasarkan latar belakang dan rumusan masalah yang menjadi fokus pembahasan dan penelitian, maka tujuan penelitian ini adalah sebagai berikut :

1. Untuk mengkaji dan menganalisis pengaturan instrumen hukum nasional dan instrument hukum internasional yang menjamin hak pendidikan anak penyandang disabilitas.

2. Untuk mengkaji dan menganalisispelaksanaanhukum dalam pemenuhan hak pendidikan bagi anak penyandang disabilitas yang sesuai dengan hak asasi manusia.

\section{METODE PENELITIAN}

Pendekatan yang digunakan dalam penelitian ini antara lain status approach (pendekatan perundang-undangan) dan analytical or conceptual approach (pendekatan analitik atau konseptual). ${ }^{7}$

Data sekunder berupa penelitian kepustakaan yang dilakukan terhadap berbagai macam sumber-sumber bahan hukum yang dapat diklasifikasi menjadi 3 (tiga) jenis, yaitu ${ }^{8}$ :

1. Bahan Hukum Primer

Bahan hukum primer merupakan bahan hukum bersifat autoritatif dan mengikat. ${ }^{9}$ Yang terdiri dari:

Adapun bahan hukum primer terdiri dari:
a. Undang-undang Dasar Republik Indonesia Tahun 1945
b. Undang-Undnag Nomor 39 Tahun 1999 tentang Hak Asasi Manusia
c. Undang-Undang RI Nomor 8 tahun 2016 tentang Penyandang Disabilitas
d. Undang-Undang No. 23 Tahun 2003 Perubahan Undang-Undang Nomor 35 Tahun 2014.
e. Undang-Undang Nomor 20 Tahun 2003 tentang Sistem Pendidikan Nasional

f. Peraturan Presiden RI Nomor 75 tahun 2015 tentang Rencana Aksi Nasional Hak Asasi Manusia Tahun 2015-2019

g. Peraturan Mentri Pemberdayaan dan Perlindungan Perempuan dan Anak RI Nomor 4 Tahun 2017 tentang Perlindungan Khusus Bagi Anak Penyandang Disabilitas.

h. Declaration Universal of Human Rights dalam bahasa Indonesia dikenal Deklarasi Universal Hak Asasi Manusia (DUHAM).

i. Konvensi Hak Anak

j. Internastional Covenant on Civil and Polotical Rights atau Konvensi Internasional tentang Hak Sipil dan Politik

\footnotetext{
${ }^{7}$ Peter Mahmud Maruki. 2005.Penelitian Hukum. Jakarta: Kencana Prenada Media Group. hlm.93.

${ }^{8}$ Soerjono Soekanto \& Sri Mamudji. 2006. Penelitian Hukum Normatif. Jakarta: PT. Radja Grafindo Persada. 13. ${ }^{9}$ Peter Mahmud Marzuki. Op.Cit. hlm. 141
} 
2. Bahan Hukum Sekunder. ${ }^{10}$

3. Bahan Hukum Tersier. ${ }^{11}$

Data yang dikumpulkan melalui studi pustaka yang dihimpun dan diolah dengan melakukan pendekatan yuridis normatif. Data yang telah dikumpulkan dengan studi kepustakaan tersebut selanjutnya dianalisis dengan menggunakan metode kualitatif yang didukung oleh logika berpikir secara deduktif.

\section{HASIL DAN PEMBAHASAN}

A. Pengaturan Instrumen Hukum Nasional dan Instrumen Hukum Internasional yang Berkaitan dengan Hak Pendidikan Anak Disabilitas

Masyarakat penyandang disabilitas global telah berusaha untuk memerangi pandangan terhadap isu disabilitas atau penyandang disabilitas sebagai objek kegiatan amal atau orang sakit yang membutuhkan kesembuhan. Mereka juga berusaha untuk mendefinisi ulang penyandang disabilitas sebagai anggota penuh dan setara dari masyarakat, yang memiliki kontribusi penting dalam keluarga dan masyarakatnya. "All human rights are closelyinterrelated and interdependent and affect oneanother", ${ }^{12}$ artinya bahwa hak setiap orang memiliki hubungan dan kemandirian dan mempunyai keterhubungan antara satu dan yang lain. Perlindungan hak asasi manusia disediakan olehCRPD tidak dipicu oleh penurunan nilai, tetapi kecacatan yaitu, perlindungan yang faktual tersedia untuk orang-orang disabilitas untuk tidak diskriminasi.

MenurutJohn Locke mengatakan bahwa walaupun masyarakat membentuk negara melalui kontrak sosial, namun hak asasi tetap melakat pada masing-masing individu, dan manusia menyerahkan sebagian hak-hak alamiahnya kepada masyarakat. ${ }^{13}$ Jadi, walaupun masyarakat membentuk negara, namun hak asasinya suatu yang kodrati yang tidak diciptakan atau diberikan oleh

\footnotetext{
${ }^{10}$ Ibid

${ }^{11}$ Jhonny Ibrahim. Op.Cit. hlm. 296

12 http://bisamandiri.com/blog/2015/01/macammacamdisabilitas-atau-gangguan-fungsi/ Anonim. Artikel Macam-Macam disabilitas Atau Gangguan Fungsi. Diakses Tanggal 14 April 2020

${ }^{13}$ F. Isjwara. 20016. Pengantar Ilmu Politik. Jakarta:

Binacipta.hlm. 107-108.
}

negara.Bahkan menurut Rousseau, ${ }^{14}$ negara mempunyai tugas utama untuk memberikan perlindungan terhadap hak asasi manusia.

Menurut K. Bertens ${ }^{15}$, HAM bukan saja sesuatu yang diperjuangkan, tetapi ada segi teoritisnya juga. Segi teoritis itu bermula dari ilmu hukum. Perlu dipikirkan bagaimana agar hak-hak manusia itu bisa dirumuskan dengan cara yang paling tepat dan disesuaikan dengan sistem hukum yang berlaku. Ilmu hukum sangat penting dalam memberi dasar yang teguh kepada HAM baik dalam sistem hukum nasional maupun internasional.

1. Pengaturan Instrumen Hukum Nasional

a. Undang-Undang Dasar 1945

b. Undang-Undang Nomor 39 Tahun 1999 tentang Hak Asasi Manusia

c. Undang-Undang 35 tahun 2014 tentang Perubahan atas UndangUndang Nomor 23 tahun 2002 tentang Perlindungan Anak

d. Undang-Undang Nomor 8 Tahun 2016 tentang Penyandang Disabilitas kaitannya dengan Undang-Undang Nomor 20 Tahun 2003 tentang Sistem Pendidikan Nasional

2. Pengaturan Instrumen Hukum Internasional

a. Deklarasi Universal Hak Asasi Manusia (The Universal Declaration of Human Rights)

b. Perjanjian Internasional tentang HakHak Ekonomi, Sosial, Budaya (International Covenant on Economic, Social and Cultural Rights)

c. Konvensi PBB tentang Hak-Hak Penyandang Disabilitas (United Nations Convention on the Rights of Persons with Disabilities)

d. Konvensi Hak-Hak Anak (The Convention on the Rights of the Child)

e. Deklarasi Winna dan Program Aksi Tahun 1993

B. PelaksanaanMengenai Pengaturan Hak Pendidikan Anak Penyandang Disabilitas Prespektif Hak Asasi Manusia

\footnotetext{
${ }^{14}$ Moh.Kusnardi dan Harmaily Ibrahim. 2010.Pengantar Hukum Tata Negara Indonesia. Jakrata: Balai Pustaka.hlm. 125.

${ }^{15}$ K. Bertens. 2000. Menyambung Refleksi tentang Pendasaran Hak Asasi Manusia. Kompas.hlm. 31.
} 
1. Pelaksanaan Hak Pendidikan Anak Penyandang Disabilitasberkaitan dengan Peraturan Presiden RI Nomor 75 tahun 2015 tentang Rencana Aksi Nasional Hak Asasi Manusia Tahun 2015-2019

Anak penyandang disabilitas termasuk terkait dengan hak asasi manusia yang harus dilindungi, dijamin dan ditegakkan oleh semua kompenan lapisan bangsa. Pengaturan pelaksanaan anak penyandang disabilitas dalam mendapatkan pendidikan bersamasama dengan non-penyandang disabilitas tidak hanya menjadi tanggung jawab pemerintah pusat, tetapi sesungguhnya juga menjadi tanggung jawab pemerintah daerah dalam konteks Negara Kesatuan Republik Indonesia.

Menurut data estimasi dari World Health Organisation (WHO) menyebutkan sekitar 20 juta rakyat Indonesia atau $10 \%$ dari seluruh penduduk Indonesia adalah penyandang cacat. Dari jumlah itu, baru $6 \%$ dari penyandang cacat itu yang tersentuh pendidikan. Sementara menurut data Indonesian Society for Special Needs Education (ISSE)lembaga yang fokus memperhatikan pendidikan bagi anak-anak berkebutuhan khusus di Indonesia, sekira 2,6 juta lebih anak berkebutuhan khusus (special needs) usia sekolah di Indonesia. Sedangkan menurut data Direktorat Pendidikan Luar Biasa, ada 1,3 juta anak difabel usia sekolah di Indonesia. Dari jumlah tersebut, yang masuk ke sekolah khusus hanya mencapai sekira 48 ribu orang. Artinya, ada lebih dari 98\% anak berkebutuhan khusus masuk dalam pendidikan nonformal, tetapi jumlahnya diperkirakan tidak lebih dari 2 persen dari 98\% tersebut. $^{16}$

Kewajiban negara baik pemerintah pusat maupun daerah untuk menyediakan akses pendidikan yang seluas-luasnya kepada seluruh warga negara.Namun dalam prakteknya, anak penyandang disabilitas sangat rentan untuk memperoleh perlakuan diskriminatif dalam memperoleh hak-haknya, termasuk hak atas pendidikan. Hal tersebut disebabkan oleh ketidak-samaan kondisi fisik atau psikis anak penyandang disabilitas.Karenanya, anak penyandang

\footnotetext{
${ }^{16}$ Diakses Artikel Kompasiana. 2019. Aksesibilitas Pendidikan Kaum Difabel.
}

disabilitas membutuhkan perlindungan dalam memperoleh pendidikan. Untuk menganalisis apakah pengaturan pelaksanaan pendidikan anak penyandang disabilitas efektif dan menggunakan teori hak asasi manusia.

Teori hak asasi manusia belum cukup membantah teoridiskriminatif dari para penyandang disabilitas kemampuan. Meskipun inti dari hak asasi manusia bahwa semua manusia memiliki martabat yang melekat pada manusia. Ahli teori hak jarang menyebutkan secara eksplisit hak-hak penyandang cacat, danketika mereka disebutkan, mereka cenderung memberikan argumen yang menelanjangi penyandang disabilitas mempunyai hak yang sama. ${ }^{17}$

Non-diskriminasi telah muncul di dalam kebijakan sektor pendidikan. Namun di tahap pelaksanaan, hak untuk diperlakukan secara setara di sekolah umum tidak dapat berjalan. Pendidikan konvensional melihat bahwa masalah disabilitas sebagai hambatan siswa untuk memperoleh pencapaian sebagaimana 'siswa normal'. Pada kebanyakan kasus, siswa yang berasal dari sekolah khusus menghadapi perlakuan diskriminasi karena pencapaian/tingkat pendidikannya direndahkan dan dibedakan. ${ }^{18}$ Mengacu pada banyaknya jumlahpenyandang disabilitas, semestinya memang tidak terjadi pembedaan perlakuan pemenuhan hak antara orang yang normal dengan penyandang disabilitas. Meskipun demikian, tidak dapat dipungkiri bahwa secara praktis banyak karya mengagumkan yang dihasilkan para anak penyandang disabilitas. $^{19}$

Menjadi penyandang disabilitas seharusnya bukanlah menjadi halangan yang berat untuk mendapatkan hak-hak dasar seperti berhak untuk hidup, berhak memperoleh layanan kesehatan yang layak, berhak untuk mendapatkan pendidikan yang layak maupun hak-hak dasar lainnya. RANHAM berkaitan dengan upaya pelaksanaan hak penyandang disabilitas di

\footnotetext{
${ }^{17}$ Gauthier de Beco. 2017. Human rights through the lens of disability. Netherlands Quarterly of Human Rights. No. 3/Vol 24. hlm. 263.

${ }^{18} \mathrm{Ibid}$

${ }^{19}$ Naskah Akademik Rancangan Undang-Undang Tentang Penyandang Disabilitas.(2014). http://www.dpr.go.id/doksileg/proses1/RJ1-20150701023052-2614.pdf. Diakses pada tanggal 20 April 2020.
} 
bidang pendidikan salah satunya adalah aksebilitas dalam penyediaan guru pendidikan inklusif, peningkatan sekolah pendidikan inklusif, dan penyediaan alat bantu belajar penyandang disabilitas di sekolah reguler. Program ini belum dapat dilaksanakan di pemerintah kota/kabupaten dalam sekolah reguler sehingga terdapat penolakan anak penyandang disabilitas yang tidak bisa sekolah dengan nonpenyandang disabilitas. RAN-HAM 2015-2019 hanya berfokus pada programprogram aksi yang menjadi rutinitas kementrian tanpa menjabarkan persoalan HAM yang terjadi di tengah masyarakat.

Pada strategi ini, diterangkan bahwa pokok permasalahan dari RANHAM 2015-2019 adalah "belum optimalnya institusi pelaksana RANHAM dalam melaksanakan RANHAM." Dari tahun ke tahun problem penguatan institusi pelaksana selalu menjadi alasan dari kebuntuan pemaksimalan pencapaian agenda RANHAM. Selain itu, nampaknya negara masih minim untuk melakukan evaluasi secara berkala dan transparan atas capaian-capaian ataupun hambatanhambatanyang ditemui dalam mendorong pemaksimalan RANHAM. Diketahui pula bahwa pada dokumen RANHAM 2015-2019 juga tidak dicantumkan badan-badan negara yang menjadi penanggung jawab, hal ini mempersulit ruang koordinasi, evaluasi dan pertanggungjawaban selama 5 tahun kedepan dari program RANHAM. ${ }^{20}$

Perlindungan dan pemenuhan hak asasi manusia maupun hak warga negara menjadi inti dari konsepsi negara hukum. Oleh karena itu, segala norma hukum yang menjadi dasar penyelenggaraan negara harus diorientasikan kepada perlindungan dan pemenuhan HAM dan hak warga negara. Hak-hak yang diatur dalam konstitusi merupakan batas yang tidak bisa dilanggar oleh penyelenggara negara dalam menjalankan kekuasaan negara, baik sebagai hak warga negara atau hak asasi.

Implementasinya pemerintah Indonesia telah membuat Rencana Aksi Hak Asasi Manusia (RANHAM) yang di antaranya berisi mengenai upaya perlindungan dan penegakan hak asasi manusia di tingkat pusat sampai daerah yang dilakukan melalui pendidikan,

20 Tim Kontras, 2015. RAN-HAM Tidak Menjawab Masalah Di Indonesia. Jakrta Pusat; Kontras. hlm. 5 penyuluhan dan sosialisasi baik bagi para penegak hukum, instansi pemerintah, siswa dan mahasiswa. Jaminan hukum di antaranya dilakukan dengan melengkapi berbagai peraturan perundangan berkaitan dengan perlindungan hak asasi manusia di antaranya dengan peratifikasian berbagai instrumen internasional yang berkaitan dengan hak asasi manusia. ${ }^{21}$

2. Kasus-Kasus Anak Penyandang Disabilitas yang Di Tolak Oleh Sekolah Di Indonesia

Pelaksanaan pendidikan anak disabilitas terdapat kasus anak disabilitas ditolak oleh sekolah dalam hal ini terdapat kesenjangan antara peraturan dan pelaksanaannya sehingga terjadi diskriminasi. Di bawah ini akan diuraikan kasus-kasus anak penyandang disabilitas di tolak di sekolahsebagai berikut:

a. Rofi Firdhan Ilham warga Rangkasbitung, Kabupaten Lebak, Banten di tolak mendaftar di SMK PGRI Rangkasbitung alasannya kaki sebelah kiri tidak bisa jalan dan diminta ke sekolah berkebutuhan khusus pada tahun 2018.

b. Sekolah SMP di Sleman menolak anak disabilitas karena belum mampu dan tidak siap menerima siswa disabilitas yang di alami Endang pada tahun 2019.

c. Kasus lain menimpa BKR, seorang anak yang memiliki hambatan mobilitas yang ditolak di beberapa sekolah dasar (SD) di Pekanbaru, dan dua anak difabel penglihatan asal Makassar yang ditolak saat melakukan pendaftaran penerimaan peserta didik baru (PPDB) SMA dan SMK di Sulawesi Selatan. ${ }^{22}$

Selanjutnya penulis mengutip hasil wawancara, dilansir dari Kompas.com Menteri Pendidikan dan Kebudayaan Nadiem Makarim dalam kesempatan peringatan Hari Guru Nasional, Senin (25/11/2019), pendidikan khusus menjadi salah satu isu penting yang perlu diperhatikan dan meminta semua guru memiliki kepedulian untuk memahami prinsipprinsip dasar pendidikan khusus.Mudah-

\footnotetext{
${ }^{21}$ Philip Alston, 2008. Hak Asasi Manusia. Yogyakarta; Pusat Studi Hak Asasi Manusia. hlm. 255

${ }^{110}$ https://nasional.sindonews.com/berita/1354131/18/m enyoal-hak-pendidikan-bagi-difabel. Diakses tanggal 10 Juli 2020. Pukul 23.00 Wita.
} 
mudahan dengan adanya perhatian khusus dari Kemendikbud sendiri menjadi penguat gerakan dan perubahan untuk pendidikan kaum difabel bisa lebih baik lagi disemua aspek. Sehingga, kaum difabel bisa memperoleh haknya untuk mendapatkan pendidikan dan pendidikan yang berkualitas. Sehingga apa yang diaamanatkan dan dicitacitakan Indonesia bisa terlaksana dan tercapai dengan baik. ${ }^{23}$

Hasil wawancara dapat disimpulkan bahwa guru bisa memahami prinsip-prinsip pendidikan khusus dan penyandang disabilitas lebih diperhatikan lagi agar penyandang disabilitas bisa memeproleh hak pendidikan yang layak dan berkualitas sehingga tidak terjadi diskriminasi.

Sebagai bentuk penolakan pada anak disabilitas, kebijakan pemerintah sebagai representasi negara dalam pendidikan mendiskriminasikan atau menghambat pendidikan dengan anak disabilitas, berpengaruh buruk pada masa depan anak dengan disabilitas. Dijelaskan dalam Convention agaist Discrimination in Educationbahwa diskriminasi merupakan tindakan membatasi atau bahkan menghilangkan akses seseorang terhadap pendidikan dari jenjang manapun. Serta mempertahankan sistem pendidikan yang terpisah untuk seseorang atau kelompok orang. Sejalan dengan itu menurut Altman ${ }^{24}$ diskriminasi terdiri dari tindakan, praktik, atau kebijakan yang menjatuhkan atau relatif merugikan pada orang-orang berdasarkan pada keanggotaan mereka dalam kelompok sosial yang menarik perhatian dan mereka biasanya tidak memenuhi persyaratan atau tidak diharapkan dalam masyarakat.

Non diskriminasi (non-discriminstion), yang terjadi jika setiap orang diperlakukan tidak setara. Misalnya, ketidaksetaraan kesempatan pendidikan. Sebuah situasi dikatakan diskriminatif atau tidak setara, jika diperlakukan secara berbeda atau situasi yang berbeda diperlakukan secara sama.

\footnotetext{
${ }^{23}$ https://akuratnews.com/menegakan-hak-pendidikankaum-difabel/. Diakses Tanggal 10 Juli 2020. Pukul 23.00 Wita.

${ }^{24}$ Altman. 2011. Discrimination. Stanfor ecyclopedia of philosophy. Juli 2020. http://plato.stanford.edu/entries/discrimination/\#DirDis.
}

Diskriminasi ada dua bentuk yaitu, diskriminasi langsung dan diskriminasi tidak langsung. Diskriminasi langsung merupakan ketika seseorang baik langsung maupun tidak langsung diperlakukan secara berbeda daripada yang lainnya.

Tanggungjawab

negara (stateresponsibility), negara melalui aparaturnya merupakan aktor utama yang dibebani tanggungjawab untuk memenuhi, melindungi, menghormati hak asasi manusia. Prinsip ini ditulis di seluruh kovenan dan kovensi hak asasi manusia internasionalnya maupun peraturan domestik. ${ }^{25}$

3. Akomodasi Yang Layak bagi Hak Pendidikan Anak Penyandang Disabilitas

Pelaksanaan hak asasi manusia berkaitan dengan hak pendidikan anak penyandang disabilitas dalam Undang-Undang Nomor 8 Tahun 2016 Tentang Penyandang disabilitas Pasal 10 berbunyi mendapatkan Akomodasi yang Layak sebagai peserta didik, penulis akan uraikan sebagai berikut:

Penyandang disabilitas disamakan dengan orang sakit dan tidak berdaya sehingga tidak perlu diberikan pendidikan dan pekerjaan. Mereka cukup dikasihani dan diasuh untuk kelangsungan hidupnya. Sehingga hal tersebut mengakibatkan penyandang disabilitas tidak mendapat hak dan kesempatan yang sama seperti warga masyarakat lainnya.

Akomodasi yang layak yang diatur dalam UU No. 8 tahun 2016 tentang Penyandang disabilitas sebenarnya bukan hal baru dalam dunia pendidikan untuk Penyandang disabilitas. Hanya saja, selama ini hal tersebut belum diatur secara eksplisit oleh UndangUndang, dan dalam implementasinya belum dirancang dan dikembangkan secara sistematis. Pengaturan pertama dalam UNCRPD (Universal Convention on the Rights of Persons with Disabilities) yang disebut "reasonable accommodation", yang berlakunya di Indonesia disahkan dengan UU No. 19 tahun 2011. Sebagai domestikasi dari UNCRPD (Universal Convention on the Rights of Persons with Disabilities), UU No. 8 tahun 2016 tentang Penyandang Disabilitas tentu juga mengaturnya. Pemenuhan akomodasi

\footnotetext{
${ }^{25}$ Hari Kurniawan, 20015. Aksesabilitas Peradilan Bagi Penyandang Disabilitas. Yogyakarta: PUSHAM UII. hIm. 25
} 
yang layak merupakan "jiwa" dari UNCRPD (Universal Convention on the Rights of Persons with Disabilities)dan UU No. 8 tahun 2016.

Tiap ragam disabilitas memiliki kebutuhan khusus yang berbeda. Olehkarenanya, akomodasi yang layak tiap ragam disabilitas pun berbeda satu dengan lainnya yaitu: ${ }^{26}$

a. siswa Penyandang tunarungu atau tuli membutuhkan akses ke komunikasi dalam proses belajar di kelas. Untuk itu, komunikasi perlu dilakukan dengan menggunakan bahasa isyarat Indonesia (bisindo) yang dikombinasikan dengan "lip reading atau membaca gerak bibir". Proses belajar untuk anak tunarungu harus lebih bersifat visual. Jika ada informasi yang bersifat audio, harus dibarengi dengan tulisan, sehingga anak tunarungu dapat memahami isi informasi tersebut.

Sebaliknya, proses pembelajaran untuk anak tunanetra yang sama sekali tidak dapat melihat (totally blind) atau kurang dapat melihat dengan jelas (low vision) harus lebih naratif. Jika ada gambar, harus dinarasikan serta dibuat dalam bentuk gambar timbul yang dapat diraba. Untuk membaca buku, anak tunanetra memerlukan buku dalam bentuk buku Braille, atau buku audio, dan / atau buku elektronik, yang tidak ada di toko buku, sehingga harus ada lembaga khusus yang memfasilitasi penyediaan buku yang aksessibel untuk tunanetra.

b. Untuk anak dengan disabilitas intelektual, pendidikan lebih ditekankan pada kemampuan anak Penyandang disabilitas intelektual untuk dapat menjalani kehidupan sehari-hari dengan baik. Olehkarenanya pendidikan untuk anak dengan disabilitas intelektual tidak terlalu menekankan pada sisi akademik melainkan lebih menekankan pada aspek fungsi. Jika anak Penyandang disabilitas intelektual belajar berhitung misalnya, proses belajar berhitung tersebut harus langsung dikaitkan

\footnotetext{
${ }^{26}$ Tanti Kirana Utami. 2019. Model Perlinduang Sosia Bagi Penyandang Disabilitas Prespektif Hak Asasi Manusia. fakultas hukum Universitas Surya kencana. Jurnal Living Law. No. 2/Volume 11.hlm. 136
}

dengan aktivitas dalam kehidupan sehari-hari, sehingga lebih kongkrit dan lebih mudah mereka pahami.

c. Untuk anak-anak yang memiliki disabilitas fisik, akomodasi yang layak yang mereka perlukan pun berbeda; Yaitu lebih bersifat akses ke tempat dan fasilitas belajar secara fisik. Misalnya, akses ke tempat yang lebih tinggi dengan menggunakan bidang miring (ram) atau lift. Bagi mereka yang tidak memiliki tangan atau ada kelemahan dengan fungsi tangan, maka, segala aktifitas - termasuk aktivitas belajar dilakukan dengan kaki.

d. Disabilitas mental merupakan kelompok Penyandang disabilitas yang baru dimasukkan ke dalam kelompok Penyandang disabilitas oleh konvensi PBB tentang Hak Penyandang Disabilitas (United Nations Convention on the Rights of Persons with Disability UN CRPD). Berdasarkan pengalaman, mereka yang mengalami disabilitas mental pada umumnya diusia awal 20an, saat mereka memulai pendidikan tinggi. Olehkarenanya akomodasi yang layak bidang pendidikan untuk Penyandang disabilitas mental hingga kini masih lebih banyak diperlukan di pendidikan.

Penyandang disabilitas mental juga memerlukan perawatan medis, sehingga mereka harus istirahat dari proses belajar. Olehkarenanya salah satu bentuk akomodasi yang layak bagi Penyandang disabilitas mental adalah fleksibilitas waktu, baik waktu belajar, waktu mengerjakan tugas atau ujian, serta waktu menempuh studi.

Orang-orang penyandang disabilitas layak untuk dimasukkan secara penuh sebagai orang yang sederajatpeserta dalam masyarakat kita, bukan karena cacat yang patut disayangkandan bukan karena termasuk orang cacat melayani keuangan garis bawahkepentingan masyarakat luas. Orangorang penyandang disabilitas layak diperlakukan secara penuhdan menyamakan peserta karena itu adalah hal yang adil untuk dilakukan. Prinsip dasar kesetaraanharus dipahami untuk melarang keputusan sosial 
yang melekat pada kerugianstatus kelompok yang distigmatisasi. ${ }^{27}$

Kesataraan (equality), perlakuan yang setara dimana pada situasi yang harus sama diperlakukan dengan sama, dan dimana pada situasi berbeda-dengan sedikit perbedaandiperlakukan secara berbeda. Kesetaraan di depan hukum, kesetaraan kesempatan, kesetaraan akses dalam pendidikan, kesetaraan dalam mengakses peradilan yang fair dan lain-lain merupakan hal penting dalam hak asasi manusia.

Penyediaan akomodasi pendidikan dalam alat bantu pembelajaran anak penyandang disabilitas dan peningkatan sekolah inklusif dalam pelaksanaannya belum optimal bahkan masih minim kesejahteraan anak penyandang disabilitas. Menjalankan tugas dalam hal penyelengaraan sekolah inklusif, Kemdikbud membuat program terpadu yang pelaksanaanya dilakukan bersama-sama kementrian lain. Diataranya, program Sekolah Ramah Anak yang dilaksanakan bersama Kementrian Pemberdayaan Perempuan dan Perlindunagan Anak Program Kesehatan Sekolah bersama Kementrian Kesehatan dan Subsidi untuk Keluarga Miskin bersama Kementrian Sosial.

Pelindungan yang diberikan oleh Pemerintah Pusatkepada Penyandang Disabilitas diwujudkan dalam beberapa sektor yang salah satunya pendidikan. Pendidikan, bagian dari pelindungan kepada masyarakat Penyandang Disabilitas karena pendidikan merupakan modal awal dalam mewujudkan kesejahteraan. Melihat pentingnya pendidikan pada seluruh masyarakat tanpa terkecuali harus dapat mengakses pendidikan. Dalam penyelenggaraan pendidikan, tidak dapat dipungkiri apabila masyarakat Penyandang Disabilitas sampai saat ini belum dapat menikmati pendidikan secara adil dan merata layaknya masyarakat yang tidak penyandang disabilitas. Belum meratanya pendidikan tersebut menyebabkan masyarakat Penyandang Disabilitas mengalami diskriminasi atas hak pendidikan. Melalui Undang-Undang Nomor 8 Tahun 2016 tentang Penyandang Disabilitas, pemenuhan hak atas

\footnotetext{
${ }^{27}$ Bagenstos, Samuel R. 2020.“Disability Rights and the Discourse of Justice". Article University of Michigan Law School SMU L. hlm. 10.
}

pendidikan diwujudkan dengan mengatur mengenai penyediaan akomodasi yang layak. Undang-Undang Nomor 8 Tahun 2016 tentang Penyandang Disabilitas menyebutkan dalam Pasal 1 angka 9 bahwa Akomodasi yang Layak dalam modifikasi dan penyesuaian yang tepat dan diperlukan untuk menjaminpenikmatan atau pelaksanaan semua hak asasi manusia dan kebebasan fundamental untuk Penyandang Disabilitas berdasarkan kesetaraan. Pengaturan akomodasi yang layak diharapkan menghapus ketidakmerataan penikmatan pendidikan karena belum tersedianya akses bagi Penyandang Disabilitas untuk menikmati pendidikan.

Kesejahteraan anak penyandang disabilitas dalam bidang pendidikan dalam adanya Sekolah Ramah HAM. Pendekatan Sekolah Ramah HAM untuk menyelesaikan beragam diskriminasi HAM di sekolah. Sekolah Ramah HAM (Human Rights Friendly School) sebuah sekolah yang mengintegrasikan nilai-nilai HAM sebagai prinsip-prinsip inti dalam organisasi dan pengelolaan sekolah, di mana nilai atau prinsip HAM menjadi pusat dari proses pembelajaran dan pengalaman serta hadir di semua sendi-sendi kehidupan sekolah tersebut.

\section{PENUTUP}

\section{A. Kesimpulan}

1. Pengaturan Hak Asasi Manusia dalam bentuk konstitusi dan hak asasi internasional dalam isu anak penyandang disabilitas sudah menjamin hak pendidikan anak penyandang disabilitas. Bahkan sudah meratifikasi konvensi-konvensi inetrnasional yang tertuang dalam peraturan nasional di Indonesia sehingga memiliki kekuatan hukum yang kuat dalam hal anak penyandang disabilitas untuk memperoleh hak asasinya.

2. Pelaksanaan mengenai pengaturan hak pendidikan anak penyandang disabilitas sebagai bentuk RAN-HAM terjadi kesenjangan antara program yang dibuat dan pelaksanaannya dan sampai saatnya belum terpenuhinya hak pendidikan anak disabilitas. Di Indonesia terdapat berbagai kasus isu anak disabilitas yang ditolak oleh sekolah 
dengan berbagai alasan. Akomodasi yang layak pun belum terjamin dalam pendidikan inklusi sehingga dalam menjamin hak pendidikan anak pendidikan melalui teori negara kesejahteraan agar negara, pemerintah bahkan masyarakan memperlakukan anak penyandang disabilitas secara adil dan non-diskriminasi. Namun, dalam fenomena isu anak disabilitas terjadi pelanggaran hak asasi manusia bentuk diskriminasi dalam menolak anak disabilitas untuk memperoleh pendidikan inklusif.

\section{B. Saran}

1. Peraturan hak pendidikan anak penyandang disabilitas sudah menjamin hak asasi manusia sehingga di harapkan negara, pemerintah bahkan sekolahsekolah peduli pada anak disabilitas dan menghilangkan diskriminasi melalui kebijakan yang menggunakan dasar hak asasi manusia. Sehingga dalam partisipasi anak dalam pendidikan dan dapat dihargai dalam masyarakat.

2. Pemerintah meninjau kembali RAN-HAM yang belum menjawab persoalan hak pendidikan anak penyandang disabilitas dan terlaksananya pendidikan bersamasama dengan non disabilitas. Pemerintah Indonesia membandingakan negara-negara yang sudah melaksanakan pendidikan inklusif tanpa diskriminasi.

\section{DAFTAR PUSTAKA}

Majda El Muhtaj. 2009. Dimensi-dimensi HAM Mengurai Hak Ekonomi, Sosial, dan Budaya. Jakarta: PT. Raja Grafindo Persada.

Majda El Muhtaj. 2008. Dimensi-Dimensi HAM Mengurai Hak Ekonomi, Sosial dan Budaya. Raja Grafindo Persada: Jakarta. hlm. 273. Bandingkan Budiyono, Muhtadi, Ade Arief Firmansyah. 2015. Dekonstruksi Urusan Pemerintahan Konkuren dalam Undang-Undang Pemerintahan Daerah. Kanun Jurnal Ilmu Hukum No. 67 Th XVII. hlm. 419432.
Peter Mahmud Maruki. 2005.Penelitian Hukum. Jakarta: Kencana Prenada Media Group.

Soerjono Soekanto \& Sri Mamudji. 2006. Penelitian Hukum Normatif. Jakarta: PT. Radja Grafindo Persada.

F. Isjwara. 20016. Pengantar IImu Politik. Jakarta: Binacipta.

Moh.Kusnardi dan Harmaily Ibrahim. 2010.Pengantar Hukum Tata Negara Indonesia. Jakrata: Balai Pustaka.

K. Bertens. 2000. Menyambung Refleksi tentang Pendasaran Hak Asasi Manusia. Kompas.

Gauthier de Beco. 2017. Human rights through the lens of disability. Netherlands Quarterly of Human Rights. No. 3/Vol 24.

Philip Alston, 2008. Hak Asasi Manusia. Yogyakarta; Pusat Studi Hak Asasi Manusia.

Hari Kurniawan, 20015. Aksesabilitas Peradilan Bagi Penyandang Disabilitas. Yogyakarta: PUSHAM UII.

Tanti Kirana Utami. 2019. Model Perlinduang Sosial Bagi Penyandang Disabilitas Prespektif Hak Asasi Manusia. fakultas hukum Universitas Surya kencana. Jurnal Living Law. No. 2/Volume 11.

Bagenstos, Samuel R. 2020."Disability Rights and the Discourse of Justice". Article University of Michigan Law School SMU L. 